\title{
Evaluating R\&D Program of the Brazilian Electricity Sector through Industrial Property Indicators
}

\author{
Josiel Gonçalves dos Santos', Cristina Gomes de Souza², Alexandre de Carvalho Castro²
}

\begin{abstract}
The Law 9,991/2000 can be considered a milestone in the history of the ANEEL R\&D Program, which was created to stimulate the technological development of the Brazilian Electricity Sector. Around $R \$ 4.5$ billion were already invested in the program, covering more than 6,000 projects. Considering the amount of resources involved, the present study aimed to evaluate the results of this program, after the Law 9,22I/2000, using industrial property indicators as a measure of performance. The research was based on a survey of the applications for patents and industrial designs, filed in the Brazilian Patent Office (INPI), by the II7 companies operating in the electricity generation segment. The findings showed: the companies that had at least one patent or industrial design application filed in the INPI after the Law 9,99I/2000; the type of protection requested; and if the content of the application was related to the goals of the program.
\end{abstract}

Keywords: r\&d projects; industrial property; patents; aneel r\&d program; brazilian electricity sector.

\footnotetext{
I FURNAS-CEFET/RJ, DIPPG, Av. Maracanã, 229 - Bloco E - 5º andar, Rio de Janeiro - RJ, 20.27I-I I 0. Phone: + 55 (2I) 2569-4495; e-mail: josielgs@gmail.com

2,3 CEFET/RJ, DIPPG, Av. Maracanã, 229 - Bloco E - 5 andar, Rio de Janeiro - RJ, 20.27I-I I 0. Phone: + 55 (2I) 2569-4495;

e-mail: ${ }^{2}$ crisgsouza@gmail.com, ${ }^{3}$ alexandre.castro@pq.cnpq.br
}

ISSN: 07 I8-2724. (http://www.jotmi.org)

Journal of Technology Management \& Innovation (c) Universidad Alberto Hurtado, Facultad de Economía y Negocios. 


\section{Introduction}

Innovation has been recognized as one of the drivers of economic growth. Several authors point out the innovation as a critical factor to the competitiveness and sustainability of the companies. In the literature on the subject, innovation is closely associated with the scientific and technological development, resulting from Research and Development (R\&D) Projects, which involve risks and require increased investment and skilled personnel (Santos et al., 20 I4; Grupp, 1998). R\&D projects can be defined as "temporary entities that conduct a series of complex and interrelated activities with predefined goals" operating as "the heart of implementing corporate innovation strategies" (Du et al., 20l4). According to Thomas et al. (20l I), the high investments that are being made in R\&D, both in developed economies and developing countries, have promoted an increasing interest in indicators to evaluate the productivity and efficiency of these projects. With this purpose, patent applications have been used as a measure to evaluate the innovation output of R\&D projects (Schwartz et al., 20I3; Beneito, 2006).

A patent is an exclusive right granted by the government to the owner of an invention, which allows to prevent others from commercially made, use, distribute, import or sell the object of that invention, without his consent, for a limited period of time (WIPO, 20I4). There are two types of patents in Brazil: invention patent and utility model patent. The invention patent protects a new product or process that provides a new way of doing something or offers a new technical solution to a problem. In turn, the utility model refers to a functional improvement in the use or manufacture of an object.

The field of industrial property rights, however, also covers other forms of protection such as industrial design. An industrial design constitutes the ornamental or aesthetic aspect of a product, making it more attractive, adding commercial value, and increasing its marketability (WIPO, 2014). Therefore, the register of industrial design application is another indicator that could be also used as output of R\&D projects.

In Brazil, the first concession contracts of electric energy forced the companies, which operated in the generation segment, to invest in research and development. In this context, it was created the ANEEL R\&D Program aiming to establish guidelines for the development of R\&D projects related to the electricity sector. The first phase of this program covered the years of 1999-2000.
In order to stimulate the technological development of the electricity sector, encouraging the constant search for innovation, the Brazilian government established the Law 9,99I, of July 24th, 2000. This law forced the concessionaires, permissionaires and authorized companies of the electricity sector to invest a higher percentage of their Net Operating Income (NOI) in R\&D as well as in energy efficiency activities. Therefore, this law increased the amount of funds to be invested in R\&D and extended this requirement to other companies of the sector. As pointed out by Almeida et al. (2012), the Law 9,99I can be considered a milestone in the history of R\&D Program of the Brazilian electricity sector. This R\&D Program is managed by the National Electric Energy Agency - ANEEL, which is an independent federal regulatory agency. ANEEL is responsible for regulate investment, approve, monitor and evaluate the projects and their results. The guidelines and instructions for elaboration of R\&D projects are defined in the Manual for Research and Development Program for the Brazilian Electric Sector (ANEEL, 20I2).

During the period of this program (until March, 2013) about $R \$ 4.54$ billion were invested covering more than 6,000 projects (ANEEL, 2013). According to information provided by the ANEEL, currently 278 companies are subject to this legal obligation.

These companies are distributed among the three segments of the Brazilian electrical system: (I) Generation - responsible for the production of electricity; (2) Transmission responsible for transporting energy to the consumption centers; and (3) Distribution - responsible for offering energy to the final consumer. Due to the size of the electrical system, this study will address only the generation segment covering 117 companies. The generation segment was selected because it embraces the most amount of companies and presents important challenges facing the growing demand for energy.

Considering the importance of the ANEEL R\&D Program for the Brazilian Electric Sector and the volume of resources involved, it is necessary to evaluate the results of the developed projects. Therefore, the identification of industrial property indicators arising from these projects can provide support to assess the nature and effectiveness of the innovative effort stimulated by this program. The evaluation of the R\&D projects is important not only for policymakers, but also for the managers to make decisions about how to select and prioritize the allocation of resources seeking higher returns and achievement of organizational goals (Ahn et al., 20l0). 
Within this context, the article aims to identify the results of the R\&D projects developed by Brazilian companies of the electricity sector, in accordance with the Law 9,99//2000, considering industrial property indicators as a measure of performance. Specifically, the findings of this study show:

(I) the electricity generation companies that participate of the ANEEL R\&D Program and have patent or industrial design applications filed in the National Institute of Industrial Property - INPI (the Brazilian Patent Office);

(2) the type of protection requested; and

(3) if the patent or industrial design applications are related to the ANEEL R\&D Program.

Therefore, these findings can contribute to a better understanding of the effectiveness of the program. The article is organized into sections. The next section discusses the patents as an indicator of innovation. The following sections present the method, the results and final considerations.

\section{Background}

Indicators are "a measure, [...] a tool that summarizes a set of information on a 'number' and therefore allows to measure certain phenomena among themselves or over a given time interval" (Kaiano and Caldas, 2002). Viotti (2005) says that the ST\&I indicators help understanding the nature and evolution of the science, technology and innovation in different historical circumstances. The concern with indicators related to scientific and technological activities is not recent. According to Soethe and Wyatt (1983), this topic has attracted interest since the SSRC Science Indicators Conference (1978) and the OECD Science and Technology Indicators Conference (1980).

The ST\&I indicators are divided into three groups: input indicators, covering expenses and human resources allocated in R\&D activities; output indicators, which show the results of ST\&I activities, usually measured through scientific publications, patent documents, and technological balance of payments; and impact indicators, which are still under construction, and seek to measure how an innovation affects the society (MCTI, 20 I4; Ferreira and Negreiros, 2005; Mugnaini et al., 2005). This study, however, is focused on the output indicators, more specifically, patent and industrial design applications.

Although the patent applications have generally been used as an indicator of innovation (Schwartz et al., 2013; Griliches 1990), there are some limitations on its use, such as: not every innovation is patentable; not every patent generates innovation; not every patent application is granted; the company may choose not to patent, preferring other technological strategies; the quality and potential of the pat- ented inventions may vary, resulting in different economic values; and cognitive aspects can influence the process of indexing, classification and retrieval of documents, interfering in the results of the surveys (Fontana et al., 2013; Jannuzzi et al., 2007; Simmons, 2005; Cohen et al., 2000). Study conducted by Mansfield (1986), for example, pointed out that the sectors of pharmacy, chemical, petroleum, machinery and fabricated metal products are more likely to patent than the sectors of primary metals, electrical equipment, instruments, office equipment, motor vehicles, rubber and textiles. Another study (Cohen et al., 2000) indicated that product innovations are more likely to be patented than process innovations. It was also found that patenting rates vary across geographical areas (Fontana et al., 2013).

On the other hand, the following factors are used as arguments for the use of patent applications as indicator of innovation: the documents are public and can be easily accessed from the internet; there is a large and growing collection of documents capable of generating statistics for long periods of time; the documents have a standardized structure and contain various information that can be strategically used for several purposes; the documents cover inventions of all technical fields and are usually published ahead of other forms of publication; the documents disclose what is new and what is expected to generate commercial return; the patents are, by definition, associated with the inventive process (Chin, 1999; Archibugi and Pianta, 1996).

Specifically in relation to patent applications to be used as indicator of R\&D projects, Lombardo (2008) mentions some aspects such as: patenting covers only a part of the R\&D activities; and patenting activity arises from several sources, for example, individual inventors, universities and other organizations, therefore it is difficult to measure the R\&D performance. According to the author, "national trend data relating patenting to $R \& D$ expendure has not developed into a strong analytical tool".

In turn, Soethe and Wyatt (1983) say that "the analysis of patent information remains one of the most established, directly available and historically reliable methods of quantifying the output of a science and technology system". Han (2007) adds that "although patents also have several drawbacks, they are, in an overall sense, the most representative of technology in terms of importance and value". Effectively, despite their limitations, the patent documents continue to be widely used to evaluate investments and results of R\&D projects (Breyer et al., 2013; Frickmann and Vasconcellos, 2013; Bergek and Bruzelius, 2010; Lombardo, 2008) and to identify innovative trends in various industries and countries (Rodríguez and Gómez, 20I I; Carvalho et al., 2009). 


\section{Method}

This is an exploratory and descriptive study based on survey data from ANEEL and INPI.The methodological procedures are described below:

(I) Identification of the companies that must invest in R\&D projects according to the national legislation: the listing of the companies was obtained through data from ANEEL. The survey indicated a total of 278 companies, including the generation, transmission and distribution segments of the electrical system in the country. As the study was restricted to the companies operating in the generation segment, this number was reduced to 117 companies.

(2) Identification of the companies with applications at the INPI: it was made a survey, considering the 117 companies covered by this study, to identify the applications for invention patent (IP), utility model patent (UM) and industrial design registration (ID) filed in the INPI.

The survey was based on the abbreviation and full name of each company according to registered in the ANEEL. It was used the WEBSEEKVS 7.4, a software developed by LDSOFT, which allows to recover data from the Industrial Property Review (IPR). IPR is the official communication vehicle of the INPI that publishes information about all processes.

(3) Information related to the companies and applications: considering the results of the survey, the following data were collected: number of the processes, status of the processes, filing date, type of protection, and tittle and abstract of the documents. From reading the title and abstract was verified the adherence of the process with the themes of the ANEEL R\&D Program.

It is important to clarify that:

- The type of protection also included industrial models (IM) and certificates of addition (CA). However, IM is not more protected in accordance with Brazilian law. In turn, CA consists of an improvement introduced in the object of an invention (it is an accessory to the content of the patent and has the same validity of the original patent).

- It was not possible to access the content of the documents in some cases because patent applications are kept confidential for a period of 18 months from the date of filing.

- Some applications were made before the ANEEL R\&D Program and promulgation of the Law 9,991/2000. Since the goal of the study was to verify the influence of this law and to evaluate the program, a filter was used to select the processes filed during the period from $07 / 2000$ to $12 / 2013$.

\section{Results}

Table I presents the results of the II7 companies covered by this study, showing the total of processes, the total of active processes and the total of processes filed in the INPI after the Law 9,99I/2000 (07/2000 to I2/2013).

\begin{tabular}{|c|c|c|c|}
\hline Company & $\begin{array}{l}\text { Total } \\
\text { of pro- } \\
\text { cesses }\end{array}$ & $\begin{array}{l}\text { Total of } \\
\text { active } \\
\text { pro- } \\
\text { cesses }\end{array}$ & $\begin{array}{c}\text { Processes } \\
\text { after Law } \\
9,991 / 2000\end{array}$ \\
\hline $\begin{array}{l}\text { PETROBRÁS - Petróleo } \\
\text { Brasileiro S/A }\end{array}$ & 1374 & 999 & 777 \\
\hline Alcoa Alumínio S/A & 291 & 263 & 214 \\
\hline $\begin{array}{l}\text { Eletronorte - Centrais Elé- } \\
\text { tricas do Norte do Brasil } \\
\text { S/A }\end{array}$ & 50 & 49 & 49 \\
\hline $\begin{array}{l}\text { CBA - Companhia Brasileira } \\
\text { de Alumínio }\end{array}$ & 41 & 37 & 40 \\
\hline $\begin{array}{l}\text { Furnas Centrais Elétricas } \\
\text { S/A }\end{array}$ & 39 & 21 & 12 \\
\hline $\begin{array}{l}\text { CEMIG Geração e Transmis- } \\
\text { são S/A }\end{array}$ & 16 & 13 & 15 \\
\hline $\begin{array}{l}\text { CESP - Companhia Energéti- } \\
\text { ca de São Paulo }\end{array}$ & 12 & 6 & 1 \\
\hline Termopernambuco S/A & 6 & 6 & 6 \\
\hline $\begin{array}{l}\text { COPEL GT - Copel Gera- } \\
\text { ção e Transmissão S/A }\end{array}$ & 4 & 4 & 4 \\
\hline Cummins Brasil Ltda & 4 & 4 & 4 \\
\hline Termo Norte Energia Ltda & 4 & 4 & 4 \\
\hline $\begin{array}{l}\text { ThyssenKrupp Companhia } \\
\text { Siderúrgica do Atlântico }\end{array}$ & 3 & 3 & 3 \\
\hline $\begin{array}{l}\text { Usina Terméletrica Norte } \\
\text { Fluminense S/A }\end{array}$ & 2 & 2 & 2 \\
\hline Aruanã Energia S/A & I & 1 & I \\
\hline $\begin{array}{l}\text { CGTF - Central Geradora } \\
\text { Termelétrica Fortaleza S/A }\end{array}$ & I & I & 1 \\
\hline $\begin{array}{l}\text { CHESF - Companhia Hidro } \\
\text { Elétrica do São Francisco }\end{array}$ & I & I & I \\
\hline ITASA - Itá Energética S/A & I & I & I \\
\hline Tractebel Energia S/A & 1 & I & 1 \\
\hline Valesul Alumínio S/A & I & I & 0 \\
\hline
\end{tabular}

Table I. Companies of the electricity sector, operating in the generation segment, with processes in the INPI.

ISSN: 07 I8-2724. (http://www.jotmi.org)

Journal of Technology Management \& Innovation (c) Universidad Alberto Hurtado, Facultad de Economía y Negocios. 
As can be observed, only 19 companies had, at least, one process filed in the INPI. Among these companies, 7 had more than 10 applications: Petrobras; Alcoa; Eletronorte; CBA; Furnas; Cemig; and CESP. Petrobras and Alcoa, together, had I,665 applications, which represent over $90 \%$ of the total. Besides the few companies that sought to protect the results of their R\&D activities through industrial property rights, there is a strong concentration in just two companies.
Table I also shows that the most of the applications was made after the Law 9,991/2000. This indicator suggests that, even in small quantity, these investments are generating some results. In turn, Table 2 presents the type of protection requested (IP - invention patent; UM - utility model; ID industrial design, IM - industrial model; and CA - certificate of addition) and the adherence of the documents with the themes proposed by ANEEL.

\begin{tabular}{|c|c|c|c|c|c|c|c|}
\hline Company & Total & IP & UM & ID & IM & CA & Adherence \\
\hline PETROBRÁS - Petróleo Brasileiro S/A & 1374 & 1316 & 17 & 31 & - & 10 & Yes \\
\hline Alcoa Alumínio S/A & 291 & 54 & 14 & 200 & 21 & 2 & Unidentified \\
\hline Eletronorte - Centrais Elétricas do Norte do Brasil S/A & 50 & 50 & - & - & - & - & Yes \\
\hline CBA - Companhia Brasileira de Alumínio & 41 & I & 5 & 35 & - & - & Unidentified \\
\hline Furnas Centrais Elétricas S/A & 39 & 25 & 13 & I & - & - & Yes \\
\hline CEMIG Geração e Transmissão S/A & 16 & 11 & 5 & - & - & - & Yes \\
\hline CESP - Companhia Energética de São Paulo & 12 & 11 & 1 & - & - & - & Yes \\
\hline Termopernambuco S/A & 6 & 6 & - & - & - & - & Yes \\
\hline COPEL GT - Copel Geração e Transmissão S/A & 4 & 3 & - & 1 & - & - & Yes \\
\hline Cummins Brasil Ltda & 4 & 4 & - & - & - & - & Unidentified \\
\hline Termo Norte Energia Ltda & 4 & 3 & 1 & - & - & - & Yes \\
\hline ThyssenKrupp Companhia Siderúrgica do Atlântico & 3 & 1 & 2 & - & - & - & Unidentified \\
\hline Usina Terméletrica Norte Fluminense S/A & 2 & 2 & - & - & - & - & Unidentified \\
\hline Aruanã Energia S/A & I & 1 & - & - & - & - & Confidential \\
\hline CGTF - Central Geradora Termelétrica Fortaleza S/A & 1 & 1 & - & - & - & - & Confidential \\
\hline CHESF - Companhia Hidro Elétrica do São Francisco & 1 & 1 & - & - & - & - & Yes \\
\hline ITASA - Itá Energética S/A & 1 & I & - & - & - & - & Confidential \\
\hline Tractebel Energia S/A & 1 & 1 & - & - & - & - & Yes \\
\hline Valesul Alumínio S/A & 1 & 1 & - & - & - & - & Unidentified \\
\hline Total & 1852 & 1493 & 58 & 268 & 21 & 12 & ----- \\
\hline
\end{tabular}

Table 2. Type of protection and adherence to the ANEEL P\&D Program.

ISSN: 07 I8-2724. (http://www.jotmi.org)

Journal of Technology Management \& Innovation (c) Universidad Alberto Hurtado, Facultad de Economía y Negocios. 
The results showed that invention patents (IP) concentrate the most of the processes of protection (approximately $81 \%$ of the total). The utility model patents (UM) accounted for a small percentage (3\%). This result is interesting since the invention patents require more inventive efforts and present greatest potential for innovation, with better prospects for economic return.

In turn, the industrial design registration accounted for $14.5 \%$ of the processes in the INPI. The industrial design was a type of protection little used by the companies covered by this study, with the exception of Alcoa and CBA. In the case of these two companies, industrial design was the most requested type of protection. It is important to note that the activities of Alcoa and CBA are concentrated in the aluminum production, which explains the lack of adherence with the themes proposed by the ANEEL. Most of the titles and abstracts of Alcoa documents, for example, are related to metallurgy technologies.

It was also not identified adherence of applications from Cummins, Thyssen Krupp, Norte Fluminense TPP and Valesul to the ANEEL R\&D Program. In the case of Petrobras, although the company does not operate in the electricity segment, it was identified technologies related to energy production. The most of applications of this company, however, are related to the activities of the oil and gas industry. It was possible to identify contents related to electricity production or other topics proposed by ANEEL in the documents of the following companies: Eletronorte, Furnas, CEMIG, CESP, Termopernambuco, COPEL, Termo Norte Energia, CHESF and Tractebel. In this group we observe companies that operate predominantly in the electricity sector. Therefore, there is a greater affinity of the projects developed under the legal obligation with the goals of the ANEEL R\&D Program.

Aruanã, CGTF and Itasa had only one application filed in the INPI. However, the documents are in the period of secrecy, so it was not possible to check their contents.

\section{Final Considerations}

This study aimed to identify the results of the R\&D projects developed by Brazilian companies of the electricity sector, in accordance with the Law 9,99//2000, considering industrial property indicators - patent and industrial design - as a measure of performance.

The findings of the survey showed that only 19 of the 117 companies covered by this study had at least one process filed in the INPI. However, in the case of 6 companies, it was not observed adherence of the contents of the processes with the themes of the ANEEL R\&D Program. It was also not possible to verify the existence of adherence in relation to other 3 companies because the period of confidentiality of the documents.

These results converge with some considerations identified in a research conducted by the Institute for Applied Economic Research (OLIVEIRA, 20I I), which highlights the existence of an adverse environment for technological innovations in the Brazilian electricity sector.According to this research, the adverse environment is due to some factors such as: the electricity sector is considered technologically mature; it is a very regulated sector; it is a sector with low competition in the country; and the most technological solutions is acquired from major international suppliers.

Although the number of applications is small, we shall note that: (I) the most of the processes was filed after the Law 9,991/2000; (2) among the 19 companies, II of them did not have processes of patent or industrial design before this law; and (3) invention patents, which require more inventive efforts, concentrate approximately $81 \%$ of the processes of protection.

Therefore, on one hand, the low quantity of patents and industrial designs can indicate a need for adjustments in the program. On the other hand, these results can be an indication that the program is presenting positive results.

However, it is important to clarify that this is an exploratory study and that the results were based on the adopted search strategy. It is also important to consider that there are other R\&D projects outputs that were not analyzed. Thus, it would be interesting to identify other results of the developed projects, in order to have a more complete evaluation of the ANEEL R\&D Program. 


\section{References}

AHN, M.J., Zwikael, O., Bednarek, R. (2010). Technological invention to product innovation: a project management approach. International Journal of Project Management, 28, 559568. doi: http://dx.doi.org/10.1016/j.jpproman.2009.II.00 I

ALMEIDA, M.F.L., Barreto JR., J.T., Frota, M.N. (20I3). Apropriação econômica de resultados de P\&D: o caso de uma empresa concessionária de energia elétrica no Brasil. In: XV Congreso Latino-lberoamericana de Gestão da Tecnologia ALTEC. INESC, Porto.

ANEEL - Agência Nacional de Energia Elétrica. (2012). Manual do programa de pesquisa e desenvolvimento do setor de energia elétrica. 20I2.ANEEL, Brasília.

ANEEL - Agência Nacional de Energia Elétrica. (20I3). P\&D Revista Pesquisa e Desenvolvimento da ANEEL, 5. http:// www.aneel.gov.br/biblioteca/downloads/livros/Revista\%20 P\&D_05.pdf. [ 13 June 2014].

ARCHIBUGI, D., Pianta, M. (1996). Measuring technological change through patents and innovation surveys. Technovation, 16, 45I-468. doi: http://dx.doi.org/10.1016/01664972(96)0003I-4.

BENEITO, P. (2006). The innovative performance of inhouse and contracted R\&D in terms of patents and utility models. Research Policy, 35 (4), 502-517. doi: http://dx.doi. org/l0.1016/j.respol.2006.0I.007.

BERGEK, A., Bruzelius, M. (20I0). Are patents with multiple inventors from different countries a good indicator of international R\&D collaboration? The case of ABB. Research Policy, 39, |32/-1334. doi: http://dx.doi.org//0.1016/j.respol.2010.08.002.

BREYER, C., Birkner, C., Meiss, J., Goldschmidt, J.C., Riede, M. (20I3). A top-down analysis: Determining photovoltaics R\&D investments from patent analysis and R\&D headcount. Energy Policy, 62, 1570-1580. doi: http://dx.doi.org/10.1016/j. enpol.2013.07.003.

CARVALHO, D. de S., De Oliveira, L.G., Winter, E., Mothé, C.G. (2009). Technological Foresight Based on Citing and Cited Patents of Cellulose with Pharmaceutical Applications. Journal of Technology Management \& Innovation. 4 (4), 32-4I. doi: http://dx.doi.org// 0.4067/s07/ 8-27242009000400003.
CHIN, L.Y. (1999). Patent information and documentation. In:World Intellectual Property Organization, Ministry of Internal \& International Commerce and Food, Government of Sri Lanka and Sri Lanka Foundation (Orgs.). WIPO regional training course on intellectual property for developing countries of Asia and the Pacific. (Online). http://www.wipo.int/ edocs/mdocs/sme/en/wipo_ip_cm_99/wipo_ip_cm_99_16. pdf. [10 April 2007].

COHEN, W. M., Nelson, R. R., Walsh, J. P. (2000). Protecting their intellectual assets: appropriability conditions and why U.S. manufacturing firms patent (or not). Working Paper 7552, National Bureau of Economic Research, Massachusetts.

DU, J., Leten, B., Vanhaverbeke, W. (20I4). Managing open innovation projects with science-based and market-based partners. Research Policy, 43, 828-840. doi: http://dx.doi. org//0.1016/j.respol.2013.12.008.

FERREIRA, S.P., Negreiros, R.M.C. (2005). Indicadores, avaliação e instrumentos de gestão: a necessidade de coordenação. Parcerias Estratégicas, 20, I095-I 109.

FONTANA, R., Nuvolari, A., Shimizu, H., Vezzulli, A. (20I3). Reassessing patent propensity: evidence from a dataset of R\&D awards, 1977-2004. Research Policy, 42, I780- I 792. doi: http://dx.doi.org/I0.10I6/j.respol.20I2.05.0I4.

FRICKMANN, F. dos S.S., Vasconcellos, A.G. (2013). Awakening the biodiversity potential trough ST\&l investments in the sector of Amazonian biotechnology. Journal of Technology Management \& Innovation, 8, 239-250. doi: http://dx.doi. org/|0.4067/s07/8-272420I3000300022.

GRILICHES, Z. (1990). Patent statistics as economic indicators: a survey. Journal of Economic Literature, 28 (4), I66I707. doi: http://dx.doi.org//0.3386/w330I.

GRUPP, H. (1998). Foundations of the economics of innovation: theory, measurement and practice. Edward Elgar Publishing, Massachusetts.

HAN, Y-J. (2007). Linking science and technology with industry. Journal of Technology Management \& Innovation. 2 (2), 7-I7.

JANNUZZI, A.H.L.; Amorim, R.C.R.; De Souza, C.G. (2007). Implicações da categorização e indexação na recuperação da informação tecnológica contida em documentos de patentes. Ciência da Informação, 36 (2), 27-34. doi: http://dx.doi. org/I0.1590/s0100-19652007000200003. 
KAYANO, J., Caldas, E.L. (2002). Indicadores para o Diálogo. GT Indicadores: Plataforma Contrapartes NOVIB. Texto de Apoio da Oficina 2. Série Indicadores. n. 8, São Paulo.

LOMBARDO, L. (2008). New indicators linking patenting and business R\&D expenditure. Scientometrics, 76 (2), 20I224. doi: |0.|007/s | | |92-007-|63|-I.

MANSFIELD, E. (1986). Patents and innovation: an empirical study. Management Science , 32, 173-181. doi: http://dx.doi. org/10.1287/mnsc.32.2.173.

MCTI - Ministério da Ciência, Tecnologia e Inovação. Indicadores Nacionais de Ciência e Tecnologia (C\&T) - Histórico. http://www.mcti.gov.br/index.php/content/view/2044/Historico.html. [28 May 20I4].

MUGNAINI, R., Jannuzzi, P.M., Quoniam, L. (2004). Indicadores bibliométricos da produção científica brasileira: uma análise a partir da base Pascal. Ciência da Informação, 33 (2), |23-|3|. doi: http://dx.doi.org//0.1590/s0/0019652004000200013.

OLIVEIRA, L.G. (20II). Tendências tecnológicas do setor elétrico. In: POMPERMAYER, F. M., DE NEGRI, F., CAVALCANTE, L.R. (Orgs.). Inovação tecnológica no setor elétrico brasileiro: uma avaliação do programa de P\&D regulado pela Aneel. IPEA, Brasília.

RODRÍGUEZ, J.C., Gómez, M. (20I I). Innovation Trends in NAFTA Countries: an Econometric Analysis of Patent Applications. Journal of Technology Management \& Innovation., 6 (3), II6-I25. doi: http://dx.doi.org//0.4067/s07/827242011000300009 .

SANTOS, D.F.L., Basso, L.F.C., Kimura, H., Kayo, E.K. (2014). Innovation efforts and performance of Brazilian firms. Journal of Business Research, 67, 527-535. doi: http://dx.doi. org/10.1016/j.jbusres.2013.11.009.

SCHWARTZ, M., Peglow, F., Fritsch, M., Günther, J. (20I2). What drives innovation output subsidized R\&D cooperation? Project-level evidence from Germany. Technovation, 32, 358-369. doi: http://dx.doi.org//0.1016/j.technovation.20I2.03.004.

SIMMONS, E.S. (2005). Trends disrupted - patent information in an era of change. World Patent Information, 27, 292 30I. doi: http://dx.doi.org/I0.1016/j.wpi.2005.05.00I.

SOETHE, L.G., Wyatt, S.M.E. (1983). The use of foreign patenting as an internationally comparable science and technology output indicator. Scientometrics, 5 ( I), 3I-54.
THOMAS, V.J., Sharma, S., Jain, S.K. (20I I). Using patents and publications to assess R\&D efficiency in the states of the USA. World Patent Information, 33, 4-10. doi: http://dx.doi. org/10.1016/j.wpi.2010.01.005.

VIOTTI, E.B. (2005). Inovação tecnológica na indústria brasileira: um exercício no uso de indicadores de inovação e algumas propostas para seu aperfeiçoamento. Parcerias Estratégicas, 20, 907-917.

WIPO - World International Property Organization. FAQs: Patents. http://www.wipo.int/patents/en/faq_patents.html. [30 April 20I4]. 